Юрій Пачковський, Ольга Дячук

УДК 316.42:339.162

Пачковський, Ю., Дячук, О. (2021). Електронна комерція в теоретичному полі соціології. Соціологічні студіï, 1(18), 14-23. https://doi.org/10.29038/2306-39712021-01-14-23

\title{
Електронна комерція в теоретичному полі соціології
}

Юрій Пачковський доктор сочіологічних наук, професор, завідувач кафедри сочіології, Львівський національний університет імені Івана Франка

Yuriy Pachkovskyy -

Doctor of Sociological Sciences, Professor, Head of the Department of Sociology, Ivan Franko National University of Lviv, Ukraine.

E-mail:pachk@ukr.net

ORCID: https://orcid.org/0000-00026076-055X

\section{Ольга Дячук -}

аспірантка кафедри сочіологї,

Львівський начіональний

університет імені Івана Франка

\section{Olha Diachuk-}

PhD student in Sociology, Ivan Franko National University of Lviv, Ukraine.

E-mail: ollga.diachuk@gmail.com ORCID: https://orcid.org/0000-00028728-9059

DOI: $10.29038 / 2306-3971-2021-01-$ 14-23

Received: May, 2021

$1^{\text {st }}$ Revision: May, 2021

Accepted: June, 2021
У статті розглянуто окремі проблеми соціологічної концептуалізації електронної комерції як соціального феномену, що набуває вагомості в сучасному глобалізованому суспільстві. Звернено увагу на низку підходів, які пропонуються до розгляду новітніх соціальних феноменів у межах економічної соціології. Серед задекларованих підходів особливе місце в аналізі електронної комерції посідає ринковий, що включає низку дискурсів: неоінституціональний, соціокультурний, феноменологічний. Доповненням до цих теоретичних концептів під час аналізу електронної комерції $\epsilon$ концептуальні положення, опрацьовані в межах теорії інформаційного суспільства: концепції мережевого суспільства М. Кастельса, суперіндустріального суспільства Е. Тоффлера. Продуктивними з погляду соціологічного аналізу електронної комерції розглянуто положення теорій, пов'язаних із розвитком цифрового суспільства: концепції четвертої промислової революції К. Шваба й нової економіки (концепція повної або часткової електронної комерції Turban, Outland, King et al.).

Pachkovskyy Yuriy, Diachuk Olha. Electronic Commerce in Theoretical Field of Sociology. The article deals with some problems of sociological conceptualization of electronic commerce as a social phenomenon that is gaining weight in modern globalized society. Attention is paid to a number of approaches that are proposed to consider the latest social phenomena in the framework of economic sociology. Among the declared approaches, a special place in the analysis of e-commerce has market approach, which includes a number of discourses: neo-institutional, sociocultural, and phenomenological. In addition to these theoretical concepts in analysis of electronic commerce are the conceptual provisions developed in the framework of the theory of information society: the concept of network society by M. Castells, the concept of super-industrial society by A. Toffler. Productive from the point of view of sociological analysis of e-commerce, the authors consider the theories related to the development of digital society: the concept of fourth industrial revolution by K. Schwab and the new economy (the concept of pure versus partial electronic commerce Turban, Outland, King et al.).

Key words: economic sociology, electronic commerce, market, consumption, information society, digital society. 


\section{ВСТУП}

Електронна комерція (англ. e-commerce) - порівняно нове явище (особливо в контексті цивілізаційного розвитку людства), яке, ставши надбанням третьої промислової революції, набуло стрімкого розвитку впродовж останніх десятиріч. Загалом електронна комерція є сферою нової високотехнологічної економіки, що включає всі фінансові та торговельні транзакції, здійснювані за допомогою комп'ютерних мереж, i бізнес-процеси, пов'язані з проведенням таких транзакцій. Поява електронної комерції нерозривно пов'язана з розвитком інформаційно-комунікаційних технологій (IКT), а іiї стрімке поширення - із доступом усе більшої кількості людей до мережі Інтернет. Такі глобальні тенденції не могли не відобразитися на одній з основних сфер суспільного життя - економічній, що відчутно впливає на трансформаційні процеси в сучасних глобалізованих суспільствах.

Динамічність розвитку, масштабність в охопленні людей і територій та здатність вносити відчутні зміни в соціально-економічні відносини роблять електронну комерцію надзвичайно актуальним предметом соціологічного теоретизування, адже вона присутня на всіх рівнях соціологічного аналізу соціальних процесів і явищ - від глобального до локального. Вона $є$ важливим елементом трансформації економічної та інших систем, змінює традиційні уявлення про споживання, впливаючи на споживчі повсякденні практики людей і бізнесові процеси.

\section{1. АНАЛІЗ ОСТАННІХ ДОСЛІДЖЕНЬ І ПУБЛІКАЦІЙ}

Аналіз останніх досліджень і публікацій засвідчує, що тема електронної комерції в соціологічному дискурсі представлена наразі мінімально, хоча активно опрацьовується в межах економіки, маркетингу, правознавства, інформатики та суміжних науках. Наукові розвідки українських і зарубіжних соціологів здебільшого стосуються вивчення споживання, споживчих практик та дослідження розвитку інформаційно-комунікаційних технологій і Інтернету - сфер, із якими безпосередньо пов'язане функціонування електронної комерції. Зокрема, різні аспекти споживання, споживчої поведінки й споживчих практик висвітлюють Н. В. Коваліско, О. І. Герус, О. М. Кузьмук, В. В. Любчук (2018), М. В. Мастинець, Р. О. Савчинський, . В. Сорокіна, I. О. Шконда (2015) та ін. Інформаційне суспільство, Інтернет та особливості взаємодії в мережі вивчали О. І. Горошко, Л. В. Калашнікова й Л. С. Черноус (2012), С. М. Коноплицький, Н. В. Коритнікова, О. О. Лобовікова, А. М. Малюк, А. О. Петренко-Лисак, Є. Я. Прохоренко, Л. Г. Скокова, В. М. Щербина та ін. Що стосується соціології електронної комерції, то наявні лише поодинокі праці (Ю. Ф. Пачковський (2014, 2018), Я.В.Зоська (2014), А. О. Максименко (2018), Ю.В.Сюсель (2013)), які висвітлюють окремі аспекти цієї теми. У зарубіжній соціології цю проблематику активно розв'язують у своїх дослідженнях А. Аль-Хараза (Al-Haraizah, 2016), В. Лі, К. Лікопп, А.-С. Фарабод, Х. Ассаді, (Licoppe, Pharabod, Assadi, 2002), Д. Люптон, П. Рой, С. Сассен, С. Сінг (Singh, 2000) та ін.

Мета статті - здійснити соціологічну концептуалізацію електронної комерції як соціального феномену.

\section{2. ВИКЛАД ОСНОВНОГО МАТЕРІАЛУ}

Електронну комерцію передусім треба розглядати як важливу й невід’ємну частину сучасного ринку та ринкових відносин, в основу яких покладено ринковий обмін, спрямований на отримання його учасниками взаємної вигоди. Відтак електронна комерція «вплетена» в цей ринковий обмін і в сучасних умовах $є$ його невід'ємною складовою частиною. Із погляду ринкового підходу вона підлягає аналізу вже сформованих думок щодо пояснюваних механізмів ринкових відносин. Відповідно до економічної соціології, на думку В. В. Радаєва, продуктивними в цьому плані $є$ вивчення й трактування ринків із позицій неоінституціонального, соціокультурного та феноменологічного дискурсів (Радаев, 2008, с. 33).

Неоінституціональний погляд на ринкові відносини (В. Бейкер, Н. Біггарт, Л. Болтанські, М. Брінтон, П. Дімаджіо, Дж. Мейєр, В. Ні, В. Пауелл, Н. Флігстін та ін.) акцентує увагу на ринку як сукупності інститутів і правил, які трактуються як регулятивні принципи, підкріплені легітимними правовими або соціальними нормами, що або дозволяють певний спосіб ринкового обміну як можливий, або передбачають його як бажаний, або, навпаки, забороняють його, вважаючи неприйнятним. 
Значення інститутів полягає в тому, що вони одночасно обмежують і стимулюють повсякденні дії учасників ринку, не усуваючи добровільності обміну, а швидше економлячи витрати пошуку потрібного варіанта, пропонують готові схеми дій, дають змогу здійснювати вибір і передбачати дії інших учасників. Відповідно, за логікою неоінституціонального підходу, на нашу думку, електронну комерцію можна розглядати як легітимний спосіб ринкового обміну, який не лише дозволений i можливий, а й за певних умов є бажаним і більш прийнятним, ніж інші способи обміну (наприклад в умовах епідемії інфекційного захворювання). Водночас у цій сфері є дії, котрі вважаються неприйнятними. У системі електронної комерції функціонують інститути, які одночасно обмежують i стимулюють повсякденні дії учасників ринку. Також вони економлять витрати пошуку потрібного варіанта, пропонують готові схеми дій, дають змогу здійснювати вибір та передбачати дії інших учасників. 3 іншого боку, інший аспект аналізу електронної комерції покладено в площину неформальної економіки з іiі неформальними (неінституціоналізованими) правилами й відносинами, що розширює предметне поле іï аналізу та викликає чи не найбільше зацікавлення в середовищі соціологів. Із цього погляду особливий інтерес для вивчення становлять такі напрями електронної комерції, як роздрібна торгівля товарами й послугами в різних соціальних мережах, групах, додатках-месенджерах, на форумах, біржах, сайтах - «дошках оголошень» тощо (т. зв. соціальна комерція) та електронний маркетинг через різні канали зв’язку з використанням IКТ. Ці сфери залишаються переважно неврегульованими формальними нормами й офіційними правилами. Соціологія має значний дослідницький потенціал у вивченні подібних феноменів, оскільки в цих сферах у результаті взаємодії встановлюються зв'язки, наповнені новими сенсами й інтерпретаціями учасників, та й самі учасники нерідко одночасно мають різні соціальні ролі як суб'єкти соціальноекономічних відносин (наприклад водночас $є$ покупцями й продавцями в певній віртуальній мережі).

Соціокультурний дискурс в економічній соціології представлений найбільш широко. Його відомими представниками є М. Аболафія, П. Бурдьє, П. Дімаджіо, Ф. Доббін, В. Зелізер та ін., які, приділяючи увагу соціальним зв'язкам й інституціональним устроям, аналізують ринок у категоріях соціального сприйняття, звичок, традицій, культурних навичок, ментальності. Ринкові інститути тут функціонують у ширших соціальних контекстах, що отримують підкріплення та обгрунтування в певній культурі (корпоративній, господарській чи бізнес-культурі). Як слушно 3 цього приводу зауважує американська соціологиня В. Зелізер, «потрібно не протиставляти ринок позаекономічним соціокультурним факторам, а розуміти його як особливу категорію соціальних відносин і культурних цінностей» (Zelizer, 1993, p. 194). Саме аксіологічний вимір тут є одним із наріжних каменів макросоціологічного аналізу ринку, що піднімає проблему соціальної відповідальності бізнесу та великих корпорацій перед суспільством, розкриває роль і значення позаекономічних чинників у розвитку господарських (підприємницьких) ініціатив та соціальної економіки, актуалізує потенціал локальних спільнот у розкритті набутого соціального капіталу в реалізації власних соціоекономічних ініціатив, проєктів тощо. На рівні суспільства соціокультурний дискурс є важливим для аналізу електронної комерції передусім як соціального феномену, що має особливий механізм впливу на суспільні та економічні процеси через споживчу (купівельну) дію. Від його сприйняття суспільством залежатиме технологічний поступ та інтегрованість соціуму в глобальніші системи економічних відносин. Щодо цього соціальна оцінка сприйняття електронної комерції в різних суспільствах залишається одним із важливих напрямів іiі соціологічного дослідження (наприклад Moorthy, Ling, Fatt et al., 2017; Bigné, Ruiz, Sanz, 2007). 3 іншого боку, розглядаючи ціннісний аспект культури, логічно припустити, що культурні особливості впливають і на здійснення купівельного вибору у сфері електронної комерції. Ю. С. Горбова та Д. О. Сироватка зазначають, що процес і характер споживання все повніше відображає спосіб життя, цінності та культуру населення певної країни. У цьому контексті споживання, 3 одного боку, залежить від основних цінностей сьогодення, підпорядковується їм та сприяє їх вираженню, а з іншого - впливає на процес формування самих цінностей (Горбова, Сироватка, 2020, с. 153).

Прихильники феноменологічного дискурсу (П. Асперс, У. Брюггер, К. Кнорр-Цетіна, Г. Б. Юдін та ін.), на думку В. Радаєва, виступають проти виведення теоретичних конструктів без розуміння того, як вони сприймаються учасниками ринку. Вважається, що інтерпретувати ринок можна лише за допомогою структури значень, вироблених його учасниками, і тих смислів, які вони вкладають у свої 
повсякденні господарські дії. Ідеться не про абстрактне (логічне) розуміння ринку як об'єкта відстороненого спостереження, а про сукупність загальних смислів, які виробляють його учасники в процесі практичного занурення у світ ринкових трансакцій (Радаев, 2008, с. 44). Розвиваючи положення феноменологічного підходу, електронну комерцію розуміємо невіддільно від практичних дій учасників ринку в цій сфері й тих значень, яких вони надають цим діям. Це приводить нас до вивчення повсякденних споживчих практик. За допомогою положень феноменологічного підходу можемо спробувати пояснити багато феноменів, починаючи від уявлень про електронну комерцію на різних етапах проникнення інформаційно-комунікаційних технологій у різні сфери суспільного життя, готовності здійснювати онлайн-покупки споживачами різних вікових категорій, бар'єрів, які стримують розвиток цієї сфери, і закінчуючи такими явищами, як довіра, лояльність покупців та репутація різних суб'єктів соціально-економічних відносин у системі електронної комерції.

У подальшій своїй соціологічній концептуалізації електронна комерція як соціальний феномен невіддільна від умов і шляхів технологічного поступу сучасного суспільства. Початок 60-х років ХX ст. є знаковим для електронної комерції (1960р. - виникнення першої системи бронювання та продажу квитків на поїзди й літаки SABRE), адже цей період ознаменувався розвитком зачатків інформаційного суспільства (Й. Масуда). Оскільки електронна комерція є надбанням інформаційного суспільства, логічно аналізувати ії в контексті теорій інформаџійного суспільства. Такий аналіз дає підставу стверджувати, що в сучасних умовах інформація та інформаційно-комунікативні технології перетворюються на один із найважливіших виробничих ресурсів і є вихідною базою для функціонування електронної комерції. Розвиваючи тезу засновника теорії постіндустріального суспільства Д. Белла про переважання кодифікованого теоретичного знання для здійснення технологічних інновацій (Bell, 1999), можемо розглядати електронну комерцію як технологічну інновацію (на певному етапі суспільного розвитку), принцип дії якої грунтується на обробці й передачі кодифікованої інформації. У контексті теорії мережевого суспільства М. Кастельса (згідно $з$ якою новий стан суспільства $є$ соціальною структурою, що характеризує інформаційну епоху розвитку суспільства, і в новій інформаційній економіці, яка охоплена мережами), виробництво знання й процесів управлінської інформації визначає продуктивність та конкурентоспроможність усіх економічних одиниць (Castells, 1996-1998), постання електронної комерції є закономірним наслідком і формою інформатизації суспільства, а мережеві форми соціальної організації активно функціонують у цій сфері. 3. Бжезинський наголошує на глобальному масштабі змін, що відбуваються в процесі інформатизації, а електронне аудіовізуальне середовище при цьому є основою організації соціальної поведінки особистості та групи (Brzezinski, 1982). Е. Тоффлер, автор теорії суперіндустріального суспільства, акцентує, що в суспільстві майбутнього зберігатиметься тенденція задоволення «персональних потреб покупців», тобто орієнтація на індивідуальність залишатиметься пріоритетом економіки (Toffler, 1987).

Електронна комерція як наслідок розвитку ІКТ сьогодні набуває глобального й масового характеру, і ця система, по суті, є електронним аудіовізуальним середовищем, у якому відбувається організація поведінки споживачів та інших учасників відносин у цій сфері. Електронна комерція як наслідок інформатизації проникає в усі сфери соціокультурного життя, трансформуючи їх; вона $€$ соціоекономічною категорією, яка сприяє соціально-економічному розвитку й суспільному благу. Електронна комерція як середовище, максимально спрямоване на задоволення потреб споживачів, створює унікальні можливості для задоволення їхніх персоналізованих потреб (т. зв. прос'юмеризм) (Diachuk, 2018, p. 158).

Зважаючи на особливості розвитку інформаційного суспільства на сучасному етапі, на наш погляд, мусимо враховувати новітні зміни, що відбулися на сучасному відтинку науково-технічного поступу. Сучасні суспільства набувають відчутно інших якостей та нових характеристик. I визначальна роль у цьому процесі належить новітнім технологіям, які набагато потужніші, швидші й розвиваються значно динамічніше, ніж технології на етапі становлення інформаційного суспільства (або, іншими словами, на етапі третьої промислової революції). Ці технології вносять відчутні зміни у всі сфери суспільного життя та пов’язані як із нанодослідженнями, «Інтернетом речей», розвитком штучного інтелекту, можливостями зміни людського тіла, так і із суттєвими трансформаціями бізнес-моделей і сфери виробництва, проривами в геоінженерії, освоєнні космосу тощо. Визначальною особливістю цих технологій $є$ те, що їх проривний розвиток можливий лише завдяки потужним 
цифровим технологіям, які з'явилися й функціонують на сучасному етапі. Відтак є сенс говорити про цифрове суспільство та аналізувати електронну комерцію в цьому контексті.

Як зазначає український соціолог В. С. Бакіров, цифровий соціум - не технічний феномен. Це феномен соціокультурний, який наповнює життя сучасної людини, іiі мотивації, життєві плани, норми, цінності принципово новими можливостями, що створюються цифровими технологіями. Ці технології (Інтернет, соціальні мережі, онлайн-сервіси тощо) не просто посилюють наш комунікативний потенціал - вони створюють новий соціокультурний простір, нові середовища соціальної інтеракції, нові соціокультурні фрейми влади, домінування, нерівності, конфліктності, ставлять нові завдання перед соціологічною теорією (Бакіров, 2021).

Етап становлення цифрового суспільства іншими словами можна назвати етапом четвертої промислової революції в розвитку людства, що відповідно концептуалізовано К. Швабом, засновником і директором Всесвітнього економічного форуму в Давосі. Його думки щодо сучасного суспільства із соціологічного погляду сьогодні означуються як концепція четвертої промислової революиї̈. Порівнюючи сучасні технологічні зміни, що трансформують усі сфери суспільного життя, iз визначальними особливостями попередніх промислових революцій, К. Шваб переконливо доводить, що на межі XX і XXI ст. унаслідок розвитку цифрових технологій розпочалася четверта промислова революція, основними ознаками якої $є$ стрімкість, ширина й глибина процесів, а також довготривалий вплив на системи (Шваб, 2019, с. 9). Цифрові технології, в основу яких покладено комп'ютерне обладнання, програмне забезпечення та мережі - не нові, однак, віддаляючись від третьої промислової революції, вони стають складнішими, удосконаленими й можуть трансформувати цілі суспільства та глобальну економіку. За масштабом і рівнем складності те, що К. Шваб вважає четвертою промисловою революцією, є абсолютно не знаним досвідом для людства. Водночас зараз ми перебуваємо лише на початку цієї трансформації, оскільки, на думку вченого, масштаб сучасної технологічної революції приведе до економічних, соціальних і культурних змін у таких феноменальних обсягах, що спрогнозувати їх майже неможливо (Шваб, 2019, с. 8, 13, 30).

Потрібно зауважити, що К. Шваб не виділяє лише інформаційні (комп'ютерні, цифрові) технології в якості основної рушійної сили суспільного розвитку, як це було під час третьої промислової революції й відображено в теоріях інформаційного суспільства. Увагу зосереджено на технологічних змінах узагалі, особливо в царинах фізичних, цифрових і біологічних технологій. Власне, це і $\epsilon$ мегатренди четвертої промислової революції. Підкреслюючи визначальну роль цифрових та інформаційних технологій у розвитку вищезазначених сфер, К. Шваб наголошує, що «саме синтез цих технологій та їх взаємодія у фізичній, цифровій та біологічній царинах відрізняють четверту промислову революцію від усіх попередніх» (Шваб, 2019, с. 13). Учений аналізує вплив новітніх технологічних змін на такі ключові сфери, як економіка, зайнятість, бізнес, споживання, політика на національному, глобальному та місцевому рівнях, суспільство загалом, а також на саму людину на індивідуальному рівні. Також К. Шваб наводить точки докорінного зламу суспільного розвитку, після проходження яких відбудеться цілісна трансформація різних світових систем на різних рівнях, що позначиться на житті основної частини населення (Deep Shift, 2015).

У цьому контексті електронна комерція постає як технологія, яка стає значно потужнішою, функціонуючи на базі сучасних цифрових технологій, проникає в усі сфери життєдіяльності суспільства й стає доступною для все більш широкого кола користувачів. Як зазначає К. Шваб, технології загалом та перехід на цифрові технології зокрема революціонізують повністю все (Шваб, 2019 , с. 14). Якщо говорити про електронну комерцію, то вона є яскравим проявом діджиталізації соціально-економічного розвитку на сучасному етапі, важливим рушієм змін в економіці та інших сферах.

Наступне важливе положення концепції четвертої промислової революції полягає в тому, що цифрова революція створює радикально нові підходи, що докорінно змінюють спосіб взаємодії й співпраці окремих людей та інституцій (Шваб, 2019, с. 23). У цьому сенсі електронну комерцію можна розглядати як форму взаємодії суб'єктів соціально-економічних відносин, яка здійснюється за допомогою інформаційно-комунікаційних та цифрових технологій і спрямована на отримання вигоди.

Ще одне варте уваги положення концепції К. Шваба сформульоване таким чином: нові способи використання технологій впливають на нашу поведінку, системи виробництва та споживання (Шваб, 
2019 , с. 8). Виходячи із зазначеного, можемо зробити висновок, що електронна комерція - це технологія цифрової економіки, яка суттєво впливає на сучасні бізнес-моделі, організаційні процеси й сферу споживання, змінюючи наявні та створюючи нові форми споживання й таким чином трансформуючи повсякденні споживчі практики.

Подібні думки про вплив діджиталізації на розвиток суспільств висловлюють й українські вчені. Зокрема, економісти М. В. Дубина та О. М. Козлянченко зазначають, що розвиток сучасного суспільства відбувається у швидкозмінному світі, який змінюється під дією процесів діджиталізації. Цифровізація стає магістральним напрямом трансформацій усіх сфер нашого життя й поступово змінюе принципи та механізми їх функціонування та розвитку. Значну роль уже на сьогодні діджиталізація відіграє й у розбудові національних економік країн, формуючи нові передумови та створюючи потенціал розвитку господарства на основі використання сучасних інформаційних технологій (Дубина, Козлянченко, 2019, с. 21).

Діджиталізація суттєво впливає на сферу електронної комерції: усе більша кількість населення отримує доступ до якісного інтернет-зв'язку, процеси передачі інформації стають більш швидкими й потужними, зростають можливості обробки зі збереження даних. Це позначається на всіх учасниках відносин, залучених у сферу електронної комерції, - на компаніях, продавцях і споживачах. Т. Хесс зі співавторами, зокрема, зазначають, що цифрова трансформація стала першочерговим завданням у порядку денному багатьох організацій (Hess, Matt, Wiesbock, Benlian, 2016).

На етапі інформаційного й цифрового суспільства розвивається економіка нового типу, яка має різні назви: «постіндустріальна економіка», «інформаційна економіка», «цифрова економіка», «економіка знань», «інтернет-економіка», «віртуальна економіка», «економіка інновацій», «неоекономіка» та ін. Усі ці підходи можна узагальнити за допомогою концепції нової економіки. Нова економіка репрезентує набір нових для суспільства економічних, фінансових і культурних явищ та відносин, в основу яких покладено новітні інформаційні технології та процеси автоматизації (інтернет, комп'ютер, планшет, мобільний телефон / смартфон, WAP, WiFi тощо). Ознаки нової економіки: комп'ютеризація, глобалізація, мережеве поєднання практично всього та всіх, суверенність користувача, ключова роль знань. Рушійною силою економіки знань $\epsilon$ інновації, а джерелом - знання, освіта, наука. Нова економіка в останнє десятиріччя все більше набуває рис креативної економіки: активно реагує на потреби сучасності й постійні зміни внаслідок появи інновацій; демонструє пріоритетне ставлення до творчої людини; має демократичну структуру менеджменту та високу маркетингову культуру, де саме клієнт виступає як головна дійова особа (Пачковський, 2019, c. 304-305).

Особливістю нової економіки є те, що взаємодія в цій сфері повністю або частково відбувається в кібервіртуальному просторі, який соціологи розглядають як якісно новий соціальний простір (Петренко-Лисак, 2012, с. 90). У цьому просторі відбуваються різні соціальні процеси та взаємодіють різні суб'єкти соціально-економічних відносин - організації, індивідуальні продавці чи надавачі послуг, споживачі й інтернет-користувачі, які є потенційними споживачами. Кожен із цих суб'єктів присутній у віртуальній реальності та в реальній дійсності. Отже, сфера електронної комерції $\epsilon$ перетином кібервіртуального простору й фізичної реальності, а діяльність, пов'язана 3 покупкою, продажем чи обміном товарів, послуг або інформації, може бути замкнена винятково в кібервіртуальній реальності або відбуватись у кібервіртуальності та фізичній реальності.

Із такого ракурсу нової економіки електронну комерцію розглядає концепція повної або часткової електронної комериії (pure versus partial electronic commerce), згідно з якою електронна комерція може бути як повною («чистою»), так і частковою, залежно від характеру її трьох основних складників: замовлення й оплата, виконання замовлення та доставка клієнтам. Кожна дія може бути реалізована фізично або за допомогою цифрових технологій. Отже, існує вісім можливих комбінацій (табл. 1). Якщо всі аспекти діяльності є електронними, маємо «чисту» електронну комерцію; якщо жодна 3 дій не виконується за допомогою цифрових технологій, не йдеться про електронну комерцію; в усіх інших випадках маємо часткову електронну комерцію. Якщо існує хоча б один аспект, який реалізовується в електронному вигляді, можемо говорити про часткову електронну комерцію (Turban, Outland, King et al., 2018, p. 7). 
Якщо розвинути положення цієї концепції в соціологічному руслі, то можна отримати цілісне уявлення про взаємодію всіх учасників відносин, залучених у сферу електронної комерції, компаній та інших суб'єктів, які є продавцями або надавачами послуг, і споживачів. Так, коли йдеться про ситуацію, де всі дії (замовлення й оплата, виконання замовлення, доставка клієнтам) здійснюються за допомогою цифрових технологій, можна говорити про нову споживчу практику, яка була не знайома пересічному споживачеві декілька десятиріч тому (а для значної частини населення Землі, яка не має доступу до Інтернету, невідома ще й досі). У ситуації, коли окремі дії (зазвичай це замовлення й оплата) реалізовуються за допомогою цифрових технологій, а інші (здійснення замовлення та доставка клієнтам) - у фізичній реальності, можна говорити про трансформацію наявних споживчих практик, коли споживачі отримують звичні матеріальні товари або послуги офлайн, виконавши при цьому певні дії онлайн.

Типи комерції

Таблиия 1

\begin{tabular}{|l|c|c|c|c|c|c|c|c|}
\hline \multicolumn{1}{|c|}{ Дія } & $\mathbf{1}$ & $\mathbf{2}$ & $\mathbf{3}$ & $\mathbf{4}$ & $\mathbf{5}$ & $\mathbf{6}$ & $\mathbf{7}$ & $\mathbf{8}$ \\
\hline Замовлення й оплата & $\Phi^{*}$ & $Ц^{* *}$ & Ц & Ц & Ц & $\Phi$ & $\Phi$ & $\Phi$ \\
\hline Виконання замовлення & $\Phi$ & $Ц$ & $Ц$ & $\Phi$ & $\Phi$ & Ц & $\Phi$ & Ц \\
\hline Доставка клієнту & $\Phi$ & Ц & $\Phi$ & $\Phi$ & Ц & Ц & Ц & $\Phi$ \\
\hline Тип комерції & $\begin{array}{l}\text { Традиційна } \\
\text { комеричія }\end{array}$ & $\begin{array}{l}\text { «Чиста» } \\
\text { електронна } \\
\text { комеричія }\end{array}$ & Часткова електронна комериія \\
\hline
\end{tabular}

*Ф - фізичні дії;

**Ц - дії, що виконуються за допомогою цифрових технологій.

Джерело: (Turban, Outland, King et al., 2018, p. 7).

Концепція повної або часткової електронної комерції є основою для розуміння особливостей виникнення нових і трансформації наявних споживчих практик у сучасних суспільствах. Проте вона не дає цілісного уявлення про повноту дій споживачів, які вони виконують під час онлайн-покупок. Зокрема, мається на увазі ситуація, коли споживачі вивчають інформацію про товари й послуги, порівнюють ціни та характеристики в мережі, після чого здійснюють покупку офлайн у традиційних магазинах чи інших торгових точках. У такій ситуації відбуваються залучення споживача у віртуальне середовище і його взаємодія в кіберпросторі, що теж потрібно розглядати як елемент сучасних споживчих практик. I хоча тут не йдеться конкретно про чисту або часткову електронну комерцію, водночас на споживача здійснюється вплив за допомогою технологій електронної комерції.

\section{ВИСНОВКИ}

Електронна комерція - це складний соціальний феномен, який є поєднанням економічного, соціального, технологічного та кібервіртуального компонентів. Цей феномен - прояв діджиталізації соціально-економічного розвитку на етапі четвертої промислової революції, важливий рушій змін в економіці та інших сферах суспільного життя. Водночас електронна комерція - це легітимний спосіб ринкового обміну, який не лише дозволений і можливий, а й за певних умов є бажаним та більш прийнятним, ніж інші способи обміну (наприклад в умовах епідемії інфекційного захворювання). Електронну комерцію можемо розглядати як форму взаємодії суб'єктів соціально-економічних відносин, яка здійснюється за допомогою інформаційно-комунікаційних та цифрових технологій i спрямована на отримання вигоди. Також електронна комерція - це технологія цифрової економіки, яка суттєво впливає на сучасні бізнес-моделі, організаційні процеси й сферу споживання, змінюючи наявні та створюючи нові форми споживання й так трансформуючи повсякденні споживчі практики.

Коли всі дії у сфері електронної комерції (замовлення та оплата, виконання замовлення, доставка клієнтам) здійснюються за допомогою цифрових технологій, можемо говорити про нову споживчу практику, яка була незнайома пересічному споживачеві декілька десятиріч тому (а для значної частини населення Землі, яка не має доступу до інтернету, невідома ще й досі). Якщо ж окремі дії реалізовуються за допомогою цифрових технологій, a інші - у фізичній реальності, можемо говорити про трансформацію наявних споживчих практик, коли споживачі отримують звичні матеріальні товари або послуги офлайн, виконавши при цьому певні дії онлайн. Сфера 
електронної комерції є перетином кібервіртуального простору й фізичної реальності. Суб'єкти в середовищі електронної комерції, взаємодіючи один з одним, чинять соціальний вплив. Якщо підходити до розгляду середовища електронної комерції як кібервіртуального простору, можна виконати аналіз чинників споживчого вибору та інших особливостей онлайн-споживання, які $€$ важливими елементами трансформації сучасних споживчих практик.

\section{ДЖЕРЕЛА ТА ЛІТЕРАТУРА}

Бакіров, В. С. (2021). Цифрове суспільство: порядок денний для соџіології. Доповідь на ХІІ Львівському соиіологічному форумі «Сучасні соџіальні трансформаџї: глобальний досвід та локальні специфікащії», м. Львів, 02 квim. 2021 р. (Відео). Отримано 17.05.2021 з https://www.facebook.com/sociologyinLviv/videos/ 945948292899782

Горбова, Ю. С., Сироватка, Д. О. (2020). Вплив соціокультурних чинників на споживчу поведінку студентської молоді. Традииї̈ та новаиії у розвитку сучасної соиіологічної науки: дослідження молодих вчених: зб. матеріалів II Всеукр. наук.-практ. конф. студентів, аспірантів та молодих учених (Київ, 26 лют. 2020 р., редкол.: Гасвська О. Б. та ін.). Київ: КНЕУ, 153-155.

Дубина, М. В., Козлянченко, О. М. (2019). Концептуальні аспекти дослідження сутності діджиталізації та іiі ролі в розвитку сучасного суспільства. Проблеми і перспективи економіки та управління, 3(19), 21-32. https://doi.org/10.25140/2411-5215-2019-3(19)-21-32

Зоська, Я. В. (2014). Социальные особенности интернет-потребления украинцев. Держава та регіони. Серія: Гуманітарні науки, 1-2 (36-37), 60-63.

Калашнікова, Л. В., Черноус, Л. С. (2012). Соціологічний аналіз аспектів інституалізації українського сегменту Інтернет. Наукові праиі [Чорноморського державного університету імені Петра Могили]. Серія: Соиіологія, 172, 28-33.

Любчук, В. (2018). Споживчі практики як тип повсякденних практик у сучасному українському суспільстві. Соиіологічні студіï, 1(12), 37-41. https://doi.org/10.29038/2306-3971-2018-01-37-41

Пачковський, Ю. Ф. (2014). Сучасний стан та особливості розвитку електронної комерції в Україні. Формування ринкової економіки в Україні, 33, 142-147.

Пачковський, Ю., Максименко, А. (2018). Інтернет-практики молодих людей у сучасному суспільстві: українсько-польський вимір. Polsko-ukraińskie doświadczenia wspótpracy euroregionalnej / Red. Rejman K., Pachkovskyy Y., Petrecka B. Jarosław: Wydawnictwo PWSTE, 91-109.

Пачковський, Ю. (2019). Нова економіка. Соціологія: терміни і поняття. Навч. словник-довідник / за заг. ред. В. М. Пічі (Ю. Ф. Пачковський, О. І. Пташник-Середюк, С. А. Щудло та ін.). Львів: Новий світ-2000, 304-305.

Петренко-Лисак, А. О. (2012). Методологічне обгрунтування навчальної дисципліни «Соціологія інтернеткомунікацій» в процесі підготовки студентів-соціологів. Актуальні проблеми соиіологіï, психологіï, педагогіки, 17, 89-96.

Радаев, В. В. (2008). Современные экономико-социологические концепции рынка. Экономическая социология, 1(9), 20-50. https://doi.org/10.17323/1726-3247-2008-1-20-50

Сюсель, Ю. В. (2013). Основні підходи до розуміння сутності інтернет-споживання у сучасному науковому дискурсі. Єдність навчання і наукових досліджень - головний принщип університету: зб. наук. праць звітно-наукової конф. викладачів університету за 2012 рік, 9-10 лютого 2013 року / уклад. Г. І. Волинка, О. В. Уваркіна, О. П. Смельянова. Київ: Вид-во НПУ ім. М. П. Драгоманова, 165-167.

Шваб, К. (2019). Четверта промислова революиія. Формуючи четверту промислову революиію / пер. з англ. Климчук Н., Лебеденко Я. Харків: Клуб сімейного дозвілля.

Шконда, I. (2015). Теоретичні підходи до соціологічних досліджень практик споживання. Соиіологічні студіï, 1(6), 34-39. https://doi.org/10.29038/2306-3971-2015-01-34-39

Al-Haraizah, A. (2016). Sociology of technology features of SMEs' e-commerce. European Journal of Computer Science and Information Technology, 1(4), 20-41.

Bell, D. (1999). The coming of post-industrial society: a venture in social forecasting. New York: Basic Books.

Bigné, E., Ruiz, C., Sanz, S. (2007). Key Drivers of Mobile Commerce Adoption. An Exploratory Study of Spanish Mobile Users. Journal of Theoretical and Applied Electronic Commerce Research, 2, 48-60. https://doi.org/10. 3390/jtaer2020013

Brzezinski, Z. (1982). Between Two Ages: America's Role in the Technetronic Era. Revised edition. Santa-Barbara: ABC-CLIO.

Castells, M. (1996-1998). Information Age: Economy, Society and Culture. Vol. I-III. Oxford: Blackwell Publishers.

Deep Shift. Technology Tipping Points and Societal Impact. Survey Report. Global Agenda Council on the Future of Software \& Society, World Economic Forum. September 2015. Retrieved May 17, 2021 from http://www3.weforum.org/docs/WEF_GAC15_Technological_Tipping_Points_report_2015.pdf 
Diachuk, O. (2018). Electronic commerce and social characteristics of consumption in information society. Visnyk of the Lviv University. Series Sociology, 12, 155-164.

Hess, T., Matt, C., Wiesbock, F., Benlian, A. (2016). Options for formulating a digital transformation strategy. MIS Quarterly Executive, 15(2), 103-111.

Licoppe, C., Pharabod, A.-S., Assadi, H. (2002). Contribution to a Sociology of E-Commerce. Réseaux, 6(116), 97140. https://doi.org/10.3917/res.116.0097

Moorthy, K., Ling, Ch. S., Fatt, Y. W. et al. (2017). Barriers of Mobile Commerce Adoption Intention: Perceptions of Generation X in Malaysia. Journal of Theoretical and Applied Electronic Commerce Research, 12(2), 37-53. https://doi.org/10.4067/s0718-18762017000200004

Singh, S. (2000). Electronic Commerce and the Sociology of Money. Sociological Research Online, 4(4), 67-75. https://doi.org/10.5153/sro.383

Toffler, A. (1987). The Third Wave. New York: Random House Value Publishing.

Turban, E., Outland, J., King, D. et al. (2018). Electronic Commerce 2018. A Managerial and Social Networks Perspective. 9th edition. New York: Springer International Publishing. DOI: 10.1007/978-3-319-58715-8

Zelizer, V. (1993). Making Multiple Monies. Explorations in Economic Sociology, Swedberg R. (ed.). New York: Russell Sage Foundation, 193-212.

\section{REFERENCES}

Al-Haraizah, A. (2016). Sociology of technology features of SMEs' e-commerce. European Journal of Computer Science and Information Technology, 1(4), 20-41.

Bakirov, V. S. (2021). Digital society: an agenda for sociology. Report at the XII Lviv Sociological Forum «Modern Social Transformations: Global Experience and Local Specifications», Lviv, April 2, 2021 (Video). Retrieved May 17, 2021 from https://www.facebook.com/sociologyinLviv/videos/945948292899782

Bell, D. (1999). The coming of post-industrial society: a venture in social forecasting. New York: Basic Books.

Bigné, E., Ruiz, C., Sanz, S. (2007). Key Drivers of Mobile Commerce Adoption. An Exploratory Study of Spanish Mobile Users. Journal of Theoretical and Applied Electronic Commerce Research, 2, 48-60. https://doi.org/10. 3390/jtaer2020013

Brzezinski, Z. (1982). Between Two Ages: America's Role in the Technetronic Era. Revised edition. Santa-Barbara: ABC-CLIO.

Castells, M. (1996-1998). Information Age: Economy, Society and Culture, vol. I-III. Oxford: Blackwell Publishers.

Deep Shift. Technology Tipping Points and Societal Impact. Survey Report. Global Agenda Council on the Future of Software \& Society, World Economic Forum. September 2015. Retrieved May 17, 2021 from http://www3.weforum.org/docs/WEF_GAC15_Technological_Tipping_Points_report_2015.pdf

Diachuk, O. (2018). Electronic commerce and social characteristics of consumption in information society. Visnyk of the Lviv University. Series Sociology, 12, 155-164.

Dubyna, M. V., Kozlianchenkp, O. M. (2019). Conceptual aspects of the study of the essence of digitalization and its role in the development of modern society. Problems and prospects of economics and management, 3(19), 21-32. https://doi.org/10.25140/2411-5215-2019-3(19)-21-32

Hess, T., Matt, C., Wiesbock, F., Benlian, A. (2016). Options for formulating a digital transformation strategy. MIS Quarterly Executive, 15(2), 103-111.

Horbova, Y. S., Syrovatka, D. O. (2020). The influence of socio-cultural factors on consumer behaviour of student youth. Traditions and innovations in the development of modern sociological science: Studies of young scientists. Papers of II All-Ukrainian scientific-practical conference of students, graduate students and young scientists (Kyiv, February 26, 2020), eds. Haievska O. B. et al., Kyiv: KNEU, 153-155.

Kalashnikova, L. V., Chernous, L. S. (2012). Sociological analysis of aspects of institutionalization of Ukrainian segment of the Internet. Scientific Papers [of Petro Mohyla Black Sea State University]. Series: Sociology, 172, 28-33.

Licoppe, C., Pharabod, A.-S., Assadi, H. (2002). Contribution to a Sociology of E-Commerce. Réseaux, 6(116), 97140. https://doi.org/10.3917/res.116.0097

Liubchuk, V. (2018). Consumer Practices as an Everyday Practices in Modern Ukrainian Society. Sociological Studios, 1(12), 37-41. https://doi.org/10.29038/2306-3971-2018-01-37-41

Moorthy, K., Ling, Ch. S., Fatt, Y. W. et al. (2017). Barriers of Mobile Commerce Adoption Intention: Perceptions of Generation X in Malaysia. Journal of Theoretical and Applied Electronic Commerce Research, 12(2), 37-53. https://doi.org/10.4067/s0718-18762017000200004

Pachkovskyy, Y. F. (2014). Current state and features of e-commerce development in Ukraine. Formation of Market Economy in Ukraine, 33, 142-147. 
Pachkovskyy, Y., Maksymenko, A. (2018). Internet practices of young people in modern society: Ukrainian-Polish dimension. Polish-Ukrainian experiences of euroregional cooperation / ed. Rejman K., Pachkovskyy Y., Petrecka B. Jarosław: PWSTE, 91-109.

Pachkovskyy, Y. (2019). New economy. Sociology: definitions and terms. Educational dictionary-reference book / eds. V. M. Picha (Y. F. Pachkovskyy, O. I. Ptashnyk-Serediuk, S. A. Shchudlo et. al.). Lviv: New World-2000, 304-305.

Petrenko-Lysak, A. O. (2012). Methodological substantiation of the discipline «Sociology of Internet Communications» in the process of training of sociology students. Actual problems of sociology, psychology, pedagogy, 17, 89-96.

Radaev, V. V. (2008). Modern economic and sociological concepts of the market. Economic Sociology, 1(9), 20-50. https://doi.org/10.17323/1726-3247-2008-1-20-50

Schwab, K. (2019). The fourth industrial revolution. Shaping the fourth industrial revolution / translated by Klymchuk N., Lebedenko Y. Kharkiv: Family leisure club.

Shkonda, I. (2015). Theoretical Approaches to the Sociological Studies of Consumption Practices. Sociological Studios, 1(6), 34-39. https://doi.org/10.29038/2306-3971-2015-01-34-39

Singh, S. (2000). Electronic Commerce and the Sociology of Money. Sociological Research Online, 4(4), 67-75. https://doi.org/10.5153/sro.383

Siusel, Y. V. (2013). Basic approaches to understanding the essence of Internet consumption in modern scientific discourse. Unity of teaching and research - the main principle of the university: Collection of scientific papers of the reporting and scientific conference of university teachers for 2012, February 9-10, 2013 / ed. H. I. Volynka, O. V. Uvarkina, O. P. Yemelianova. Kyiv: Publishing Houseof National Pedagogical Dragomanov University, 165-167.

Toffler, A. (1987). The Third Wave. New York: Random House Value Publishing.

Turban, E., Outland, J., King, D. et al. (2018). Electronic Commerce 2018. A Managerial and Social Networks Perspective. 9th edition. New York: Springer International Publishing. DOI: 10.1007/978-3-319-58715-8

Zelizer, V. (1993). Making Multiple Monies. Explorations in Economic Sociology, Swedberg R. (ed.). New York: Russell Sage Foundation, 193-212.

Zoska, Y. V. (2014). Social features of Internet consumption of Ukrainians. State and regions. Series: Humanities, 1-2 (36-37), 60-63. 